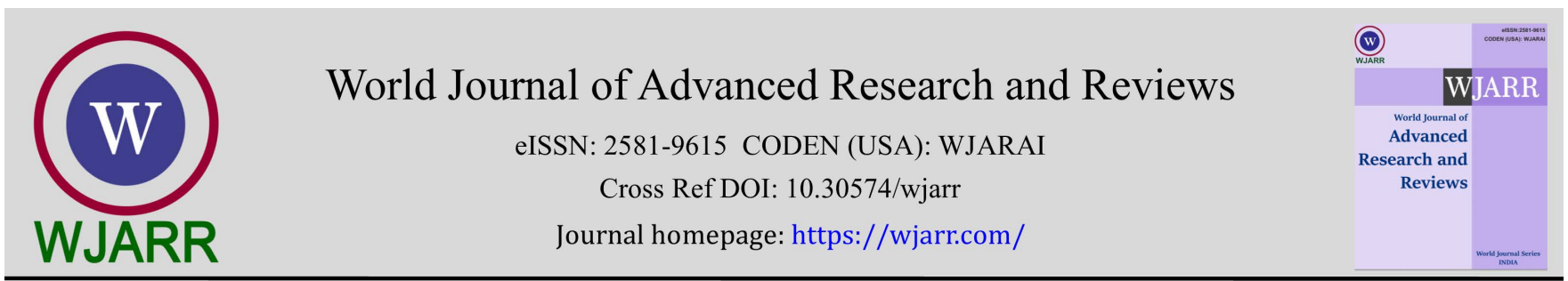

(RESEARCH ARTICLE)

\title{
Determination of twenty chemical element contents in normal and goitrous thyroid using X-ray fluorescent and neutron activation analysis
}

\author{
Vladimir Zaichick * \\ Department of Radionuclide Diagnostics, Medical Radiological Research Center, Korolyev St.- 4, Obninsk 249036, Kaluga \\ Region, Russia.
}

World Journal of Advanced Research and Reviews, 2021, 11(02), 130-146

Publication history: Received on 26 June 2021; revised on 10 August 2021; accepted on 12 August 2021

Article DOI: https://doi.org/10.30574/wjarr.2021.11.2.0352

\begin{abstract}
Nodular goiter (NG) is an internationally important health problem. The aim of this exploratory study was to examine the content of silver (Ag), bromine (Br), calcium (Ca), chlorine (Cl), cobalt (Co), chromium ( $\mathrm{Cr}$ ), cooper (Cu), iron (Fe), mercury (Hg), iodine (I), potassium (K), magnesium (Mg), manganese (Mn), sodium (Na), rubidium (Rb), ammonium $(\mathrm{Sb})$, scandium (Sc), selenium (Se), strontium (Sr), and zinc ( $\mathrm{Zn}$ ) in the normal thyroid and in the thyroid tissues with diagnosed colloid NG.. Thyroid tissue levels of twenty chemical elements (ChE) were prospectively evaluated in 46 patients with NG and 105 healthy inhabitants. Measurements were performed using non-destructive energy-dispersive $\mathrm{X}$-Ray fluorescent analysis combined with instrumental neutron activation analysis with high resolution spectrometry of short- and long-lived radionuclides. Tissue samples were divided into two portions. One was used for morphological study while the other was intended for ChE analysis. It was found that during a goitrous transformation the levels of Ag, $\mathrm{Br}, \mathrm{Cl}, \mathrm{Co}, \mathrm{Cu}, \mathrm{Fe}, \mathrm{Hg}, \mathrm{Mg}, \mathrm{Na}$, and $\mathrm{Sc}$ in thyroid tissue significantly increased, whereas the levels of I and Sr decrease. It was supposed that the changes in levels $\mathrm{Ag}, \mathrm{Br}, \mathrm{Cl}, \mathrm{Co}, \mathrm{Cu}, \mathrm{Fe}, \mathrm{Hg}, \mathrm{I}, \mathrm{Mg}, \mathrm{Na}$, Sc, and Sr in thyroid tissue can be used as NG markers.
\end{abstract}

Keywords: Colloid nodular goiters; Intact thyroid; Chemical elements; Energy-dispersive X-ray fluorescent analysis; Instrumental neutron activation analysis

\section{Introduction}

No less than $10 \%$ of the world population is affected by goiter detected during the examination and palpation and most of these thyroidal lesions are nodular goiters (NG) [1]. However, using ultrasonography NG can be detected in almost $70 \%$ of the general population [2]. NG is also known as endemic nodular goitre, simple goitre, nodular hyperplasia, nontoxic uninodular goitre or multinodular goiter [3]. NG is benign lesions; however, during clinical examination, they can mimic malignant tumors. NG can be hyperfunctioning, hypofunctioning, and normal functioning. Euthyroid NG is defined as a local enlargement of thyroid without accompanying disturbance in thyroid function [3].

For over 20th century, there was the dominant opinion that NG is the simple consequence of iodine (I) deficiency. However, it was found that NG is a frequent disease even in those countries and regions where the population is never exposed to I shortage [4]. Moreover, it was shown that I excess has severe consequences on human health and associated with the presence of thyroidal disfunctions and autoimmunity, NG and diffuse goiter, benign and malignant tumors of gland [5-8]. It was also demonstrated that besides the I deficiency and excess many other dietary, environmental, and occupational factors are associated with the NG incidence [9-11]. Among them a disturbance of evolutionary stable

\footnotetext{
${ }^{*}$ Corresponding author: Vladimir Zaichick

Department of Radionuclide Diagnostics, Medical Radiological Research Center, Korolyev St.- 4, Obninsk 249036,Kaluga Region, Russia.
}

Copyright (C) 2021 Author(s) retain the copyright of this article. This article is published under the terms of the Creative Commons Attribution Liscense 4.0. 
input of many (ChE) in human body after industrial revolution plays a significant role in etiology of thyroidal disorders [12].

Besides I involved in thyroid function, other ChE have also essential physiological functions such as maintenance and regulation of cell function, gene regulation, activation or inhibition of enzymatic reactions, and regulation of membrane function [13]. Essential or toxic (goitrogenic, mutagenic, carcinogenic) properties of ChE depend on tissue-specific need or tolerance, respectively [13]. Excessive accumulation or an imbalance of the ChE may disturb the cell functions and may result in cellular degeneration, death, benign or malignant transformation [13-15].

In our previous studies the complex of in vivo and in vitro nuclear analytical and related methods was developed and used for the investigation of I and other ChE contents in the normal and pathological thyroid [16-22]. Level of I in the normal thyroid was investigated in relation to age, gender and some non-thyroidal diseases [23,24]. After that, variations of ChE content with age in the thyroid of males and females were studied and age- and gender-dependence of some ChE was observed [25-41]. Furthermore, a significant difference between some ChE contents in normal and cancerous thyroid was demonstrated [42-47].

To date, the pathogenesis of NG has to be considered as multifactorial. The present study was performed to clarify the role of twenty $\mathrm{ChE}$ in the maintenance of thyroid growth and goitrogenesis. Having this in mind, our aim was to assess the silver $(\mathrm{Ag})$, bromine $(\mathrm{Br})$, calcium $(\mathrm{Ca})$, chlorine $(\mathrm{Cl})$, cobalt $(\mathrm{Co})$, chromium $(\mathrm{Cr})$, cooper $(\mathrm{Cu})$, iron $(\mathrm{Fe})$, mercury $(\mathrm{Hg})$, I, potassium (K), magnesium (Mg), manganese (Mn), sodium (Na), rubidium (Rb), ammonium (Sb), scandium (Sc), selenium (Se), strontium (Sr), and zinc ( $\mathrm{Zn}$ ) contents in NG tissue using energy dispersive X-ray fluorescent analysis (EDXRF) combined with non-destructive instrumental neutron activation analysis with high resolution spectrometry of sort-lived radionuclides (INAA-SLR) and long-lived radionuclides (INAA-LLR). A further aim was to compare the levels of these twenty ChE in the goitrous thyroid with those in intact (normal) gland of apparently healthy persons.

\section{Material and methods}

\subsection{Samples}

All patients suffered from NG ( $n=46$, mean age $M \pm S D$ was $48 \pm 12$ years, range 30-64) were hospitalized in the Head and Neck Department of the Medical Radiological Research Centre. Thick-needle puncture biopsy of suspicious nodules of the thyroid was performed for every patient, to permit morphological study of thyroid tissue at these sites and to estimate their ChE contents. For all patients the diagnosis has been confirmed by clinical and morphological results obtained during studies of biopsy and resected materials. Histological conclusion for all thyroidal lesions was the colloid NG.

Normal thyroids for the control group samples were removed at necropsy from 105 deceased (mean age $44 \pm 21$ years, range 2-87), who had died suddenly. The majority of deaths were due to trauma. A histological examination in the control group was used to control the age norm conformity, as well as to confirm the absence of micro-nodules and latent cancer.

All tissue samples were divided into two portions using a titanium scalpel [48]. One was used for morphological study while the other was intended for chemical element analysis. After the samples intended for chemical element analysis were weighed, they were freeze-dried and homogenized [49].

\subsection{Sample preparation and methods}

For EDXRF the pounded sample weighing about $8 \mathrm{mg}$ was applied to the piece of Scotch tape serving as an adhesive fixing backing. The content of $\mathrm{Br}, \mathrm{Cu}, \mathrm{Fe}, \mathrm{Rb}, \mathrm{Sr}$, and $\mathrm{Zn}$ were determined by EDXRF. Details of the relevant facility for this method, source with ${ }^{109} \mathrm{Cd}$ radionuclide, methods of analysis and the results of quality control were presented in our earlier publications concerning the EDXRF of ChE contents in human thyroid and prostate tissue [25, 26, 50].

The pounded samples weighing about 5-10 mg (for biopsy) and $100 \mathrm{mg}$ (for resected materials) were used for chemical element measurement by INAA-SLR. The samples for INAA-SLR were sealed separately in thin polyethylene films washed beforehand with acetone and rectified alcohol. The sealed samples were placed in labeled polyethylene ampoules. The content of $\mathrm{Br}, \mathrm{Ca}, \mathrm{Cl}, \mathrm{I}, \mathrm{K}, \mathrm{Mg}, \mathrm{Mn}$, and $\mathrm{Na}$ were determined by INAA-SLR using a horizontal channel equipped with the pneumatic rabbit system of the WWR-c research nuclear reactor (Branch of Karpov Institute, Obninsk). Details of used neutron flux, nuclear reactions, radionuclides, gamma-energies, and spectrometric unit were 
presented in our earlier publications concerning the INAA-SLR of ChE contents in human thyroid, scalp hair, and prostate [27,28,51-53]

In a few days after INAA-SLR all thyroid samples were repacked separately in a high-purity aluminum foil washed with rectified alcohol beforehand and placed in a nitric acid-washed quartz ampoule and used for INAA-LLR. A vertical channel of the WWR-c research nuclear reactor (Branch of Karpov Institute, Obninsk).was applied to determine the content of $\mathrm{Ag}, \mathrm{Co}, \mathrm{Cr}, \mathrm{Fe}, \mathrm{Hg}, \mathrm{Rb}, \mathrm{Sb}, \mathrm{Sc}, \mathrm{Se}$, and $\mathrm{Zn}$ by INAA-LLR. Details of used neutron flux, nuclear reactions, radionuclides, gamma-energies, and spectrometric unit were presented in our earlier publications concerning the INAALLR of ChE contents in human thyroid, scalp hair, and prostate [29,30,51,54].

\subsection{Standards and certified reference materials}

To determine contents of the elements by comparison with a known standard, biological synthetic standards (BSS) prepared from phenol-formaldehyde resins were used [55]. In addition to BSS, aliquots of commercial, chemically pure compounds were also used as standards. For each method ten certified reference material IAEA H-4 (animal muscle) and IAEA HH-1 (human hair) sub-samples were treated and analyzed in the same conditions that thyroid samples to estimate the precision and accuracy of results.

\subsection{Statistical analysis}

A dedicated computer program for INAA mode optimization was used [56]. All thyroid samples were prepared in duplicate, and mean values of ChE contents were used. Mean values of ChEcontents were used in final calculation for the $\mathrm{Br}, \mathrm{Fe}, \mathrm{Rb}$, and $\mathrm{Zn}$ mass fractions measured by two methods. Using Microsoft Office Excel, a summary of the statistics, including, arithmetic mean, standard deviation, standard error of mean, minimum and maximum values, median, percentiles with 0.025 and 0.975 levels was calculated for ChE contents. The difference in the results between two groups (normal and goitrous thyroid) was evaluated by the parametric Student's $t$-test and non-parametric WilcoxonMann-Whitney $U$-test.

\section{Results}

Table 1 depicts our data for $\mathrm{Ag}$, Br, Ca, Cl, Co, Cr, Cu, Fe, Hg, I, K, Mg, Mn, Na, Rb, Sb, Sc, Se, Sr, and Zn mass fraction mass fractions in ten sub-samples of IAEA H-4 (animal muscle) and IAEA HH-1 (human hair) certified reference material and the certified values of this material.

Table 1 EDXRF, INAA-SLR and INAA-LLR data of chemical element contents in certified reference material IAEA H-4 (animal muscle) and IAEA HH-1 (human hair) compared to certified values (( $\mathrm{mg} / \mathrm{kg}$, dry mass basis).

\begin{tabular}{|l|l|l|l|l|}
\hline Element & $\begin{array}{l}\text { IAEA H-4 } \\
\text { animal muscle }\end{array}$ & $\begin{array}{l}\text { This work } \\
\text { results }\end{array}$ & $\begin{array}{l}\text { IAEA HH-1 } \\
\text { human hair }\end{array}$ & $\begin{array}{l}\text { This work } \\
\text { results }\end{array}$ \\
\hline $\mathrm{Ag}$ & - & $0.033 \pm 0.008$ & $0.19 \pm 0.06^{\mathrm{b}}$ & $0.18 \pm 0.05$ \\
\hline $\mathrm{Br}$ & $4.1 \pm 1.1^{\mathrm{a}}$ & $5.0 \pm 09$ & $4.2 \pm 2.1^{\mathrm{b}}$ & $3.9 \pm 1.6$ \\
\hline $\mathrm{Ca}$ & $188 \pm 58^{\mathrm{b}}$ & $238 \pm 59$ & $522 \pm 160^{\mathrm{a}}$ & $525 \pm 42$ \\
\hline $\mathrm{Cl}$ & $1890 \pm 130^{\mathrm{b}}$ & $1950 \pm 230$ & $2265 \pm 478^{\mathrm{a}}$ & $2210 \pm 340$ \\
\hline $\mathrm{Co}$ & $0.0027 \pm 0.0010^{\mathrm{b}}$ & $0.0034 \pm 0.0008$ & $5.97 \pm 0.42^{\mathrm{a}}$ & $5.4 \pm 1.1$ \\
\hline $\mathrm{Cr}$ & $0.06 \pm 0.04^{\mathrm{b}}$ & $0.071 \pm 0.010$ & $0.27 \pm 0.16^{\mathrm{b}}$ & $\leq 0.3$ \\
\hline $\mathrm{Cu}$ & $4.0 \pm 1.0^{\mathrm{a}}$ & $3.9 \pm 1.1$ & $10.2 \pm 3.2^{\mathrm{a}}$ & - \\
\hline $\mathrm{Fe}$ & $49.1 \pm 6.5^{\mathrm{a}}$ & $47.0 \pm 1.0$ & $23.7 \pm 3.1^{\mathrm{a}}$ & $25.1 \pm 4.3$ \\
\hline $\mathrm{Hg}$ & $0.014 \pm 0.005^{\mathrm{b}}$ & $0.015 \pm 0.004$ & $1.70 \pm 0.09^{\mathrm{a}}$ & $1.54 \pm 0.14$ \\
\hline $\mathrm{I}$ & $0.08 \pm 0.10^{\mathrm{b}}$ & $<1.0$ & $20.3 \pm 8.9^{\mathrm{b}}$ & $19.1 \pm 6.2$ \\
\hline $\mathrm{K}$ & $15840 \pm 1440^{\mathrm{a}}$ & $16200 \pm 3800$ & $9.2 \pm 5.2^{\mathrm{b}}$ & $10.7 \pm 4.0$ \\
\hline $\mathrm{Mg}$ & $1050 \pm 140^{\mathrm{a}}$ & $1100 \pm 190$ & $62.0 \pm 9.6^{\mathrm{b}}$ & $64.7 \pm 18.6$ \\
\hline
\end{tabular}


World Journal of Advanced Research and Reviews, 2021, 11(02), 130-146

\begin{tabular}{|l|l|l|l|l|}
\hline $\mathrm{Mn}$ & $0.52 \pm 0.08^{\mathrm{a}}$ & $0.55 \pm 0.11$ & $0.85 \pm 0.25^{\mathrm{a}}$ & $0.93 \pm 0.16$ \\
\hline $\mathrm{Na}$ & $2060 \pm 330^{\mathrm{a}}$ & $2190 \pm 140$ & $12.6 \pm 4.8^{\mathrm{b}}$ & $14.0 \pm 2.7$ \\
\hline $\mathrm{Rb}$ & $18.7 \pm 3.5^{\mathrm{a}}$ & $22 \pm 4$ & $0.94 \pm 0.09^{\mathrm{b}}$ & $0.89 \pm 0.17$ \\
\hline $\mathrm{Sb}$ & $0.0056 \pm 0.0031^{\mathrm{b}}$ & $0.0061 \pm 0.0021$ & $0.031 \pm 0.010^{\mathrm{b}}$ & $0.033 \pm 0.009$ \\
\hline $\mathrm{Sc}$ & $0.0059 \pm 0.0034^{\mathrm{b}}$ & $0.0015 \pm 0.0009$ & - & - \\
\hline $\mathrm{Se}$ & $0.28 \pm 0.08^{\mathrm{a}}$ & $0.281 \pm 0.014$ & $0.35 \pm 0.02^{\mathrm{a}}$ & $0.37 \pm 0.08$ \\
\hline $\mathrm{Sr}$ & - & $<1$ & $0.82 \pm 0.16^{\mathrm{b}}$ & $1.24 \pm 0.57$ \\
\hline $\mathrm{Zn}$ & $86.3 \pm 11.5^{\mathrm{a}}$ & $91 \pm 2$ & $174 \pm 9^{\mathrm{a}}$ & $173 \pm 17$ \\
\hline
\end{tabular}

The comparison of our results for the $\mathrm{Br}, \mathrm{Fe}, \mathrm{Rb}$, and $\mathrm{Zn}$ mass fractions (mg/kg, dry mass basis) in the normal human thyroid obtained by both EDXRF and INAA methods is shown in Table 2.

Table 2 Comparison of the mean values $(\mathrm{M} \pm \mathrm{SD}$ ) of the chemical element mass fractions ( $\mathrm{mg} / \mathrm{kg}$, dry mass basis) in the normal human thyroid obtained by both EDXRF and INAA methods

\begin{tabular}{|c|l|l|c|}
\hline Element & \multicolumn{1}{|c|}{ EDXRF (M1) } & \multicolumn{1}{|c|}{ INAA (M2) } & $\Delta=[(\mathbf{M 1}-\mathbf{M 2}) / \mathbf{M 1}] \cdot \mathbf{1 0 0} \%$ \\
\hline $\mathrm{Br}$ & $13.9 \pm 12.0$ & $16.3 \pm 11.6$ (INAA-SLR) & -17.3 \\
\hline $\mathrm{Fe}$ & $222 \pm 102$ & $225 \pm 100$ (INAA-LLR) & -1.4 \\
\hline $\mathrm{Rb}$ & $9.03 \pm 6.17$ & $7.37 \pm 4.10$ (INAA-LLR) & 18.4 \\
\hline $\mathrm{Zn}$ & $112 \pm 44$ & $98 \pm 42$ (INAA-LLR) & 12.5 \\
\hline \multicolumn{4}{|c|}{ M - arithmetic mean, SD- standard deviation } \\
\end{tabular}

Table 3 presents certain statistical parameters (arithmetic mean, standard deviation, standard error of mean, minimal and maximal values, median, percentiles with 0.025 and 0.975 levels) of the $\mathrm{Ag}, \mathrm{Br}, \mathrm{Ca}, \mathrm{Cl}, \mathrm{Co}, \mathrm{Cr}, \mathrm{Cu}, \mathrm{Fe}, \mathrm{Hg}, \mathrm{I}, \mathrm{K}, \mathrm{Mg}, \mathrm{Mn}$, $\mathrm{Na}, \mathrm{Rb}, \mathrm{Sb}, \mathrm{Sc}, \mathrm{Se}, \mathrm{Sr}$, and $\mathrm{Zn}$ mass fraction mass fraction in normal and goitrous thyroid.

Table 3 Some statistical parameters of $\mathrm{Ag}, \mathrm{Br}, \mathrm{Ca}, \mathrm{Cl}, \mathrm{Co}, \mathrm{Cr}$, $\mathrm{Cu}$, Fe, $\mathrm{Hg}, \mathrm{I}, \mathrm{K}, \mathrm{Mg}, \mathrm{Mn}, \mathrm{Na}, \mathrm{Rb}, \mathrm{Sb}, \mathrm{Sc}$, Se, $\mathrm{Sr}$, and $\mathrm{Zn}$ mass fraction (mg/kg, dry mass basis) in normal thyroid and colloid nodular goiter

\begin{tabular}{|c|c|c|c|c|c|c|c|c|c|}
\hline Tissue & Element & Mean & SD & SEM & Min & Max & Median & P 0.025 & P 0.975 \\
\hline Normal & $\mathrm{Ag}$ & 0.0151 & 0.0140 & 0.0016 & 0.0012 & 0.0800 & 0.0121 & 0.0017 & 0.0454 \\
\hline $\mathrm{n}=105$ & $\mathrm{Br}$ & 14.9 & 11.0 & 1.2 & 1.90 & 54.1 & 11.6 & 2.56 & 49.3 \\
\hline & $\mathrm{Ca}$ & 1711 & 1022 & 109 & 414 & 6230 & 1458 & 460 & 3805 \\
\hline & $\mathrm{Cl}$ & 3400 & 1452 & 174 & 1030 & 6000 & 3470 & 1244 & 5869 \\
\hline & $\mathrm{Co}$ & 0.0399 & 0.0271 & 0.0030 & 0.0046 & 0.140 & 0.0327 & 0.0134 & 0.124 \\
\hline & $\mathrm{Cr}$ & 0.539 & 0.272 & 0.032 & 0.130 & 1.30 & 0.477 & 0.158 & 1.08 \\
\hline & $\mathrm{Cu}$ & 4.23 & 1.52 & 0.18 & 0.500 & 7.50 & 4.15 & 1.57 & 7.27 \\
\hline & $\mathrm{Fe}$ & 223 & 93 & 10 & 51.0 & 512 & 221 & 74.2 & 433 \\
\hline & $\mathrm{Hg}$ & 0.0421 & 0.0358 & 0.0041 & 0.0065 & 0.180 & 0.0304 & 0.0091 & 0.150 \\
\hline & $\mathrm{I}$ & 1841 & 1027 & 107 & 114 & 5061 & 1695 & 230 & 4232 \\
\hline & $\mathrm{K}$ & 6071 & 2773 & 306 & 1740 & 14300 & 5477 & 2541 & 13285 \\
\hline & $\mathrm{Mg}$ & 285 & 139 & 17 & 66.0 & 930 & 271 & 81.6 & 541 \\
\hline & $\mathrm{Mn}$ & 1.35 & 0.54 & 0.07 & 0.510 & 4.18 & 1.32 & 0.537 & 2.23 \\
\hline & $\mathrm{Na}$ & 6702 & 1764 & 178 & 3050 & 13453 & 6690 & 3855 & 10709 \\
\hline & $\mathrm{Rb}$ & 8.16 & 4.55 & 0.49 & 1.66 & 29.4 & 7.37 & 3.08 & 19.3 \\
\hline
\end{tabular}


World Journal of Advanced Research and Reviews, 2021, 11(02), 130-146

\begin{tabular}{|c|c|c|c|c|c|c|c|c|c|}
\hline & $\mathrm{Sb}$ & 0.111 & 0.072 & 0.008 & 0.0047 & 0.308 & 0.103 & 0.0117 & 0.280 \\
\hline & $\mathrm{Sc}$ & 0.0046 & 0.0038 & 0.0008 & 0.0002 & 0.0143 & 0.0042 & 0.00035 & 0.0131 \\
\hline & $\mathrm{Se}$ & 2.32 & 1.29 & 0.14 & 0.439 & 5.80 & 2.01 & 0.775 & 5.65 \\
\hline & $\mathrm{Sr}$ & 4.55 & 3.22 & 0.37 & 0.100 & 13.7 & 3.70 & 0.483 & 12.3 \\
\hline & $\mathrm{Zn}$ & 105.1 & 40.1 & 4.3 & 7.10 & 221 & 104.9 & 39.2 & 186 \\
\hline Goiter & $\mathrm{Ag}$ & 0.226 & 0.236 & 0.042 & 0.0020 & 0.874 & 0.160 & 0.0020 & 0.849 \\
\hline $\mathrm{n}=46$ & $\mathrm{Br}$ & 36.3 & 31.3 & 7.0 & 8.00 & 131 & 26.6 & 8.95 & 110 \\
\hline & $\mathrm{Ca}$ & 1393 & 855 & 168 & 209 & 4333 & 1280 & 258 & 3210 \\
\hline & $\mathrm{Cl}$ & 9117 & 3866 & 1223 & 4226 & 16786 & 8259 & 4504 & 15869 \\
\hline & $\mathrm{Co}$ & 0.0628 & 0.0287 & 0.0050 & 0.0150 & 0.147 & 0.0623 & 0.0215 & 0.128 \\
\hline & $\mathrm{Cr}$ & 0.849 & 0.834 & 0.150 & 0.135 & 3.65 & 0.540 & 0.142 & 2.89 \\
\hline & $\mathrm{Cu}$ & 8.51 & 7.15 & 1.60 & 2.90 & 34.8 & 5.95 & 3.00 & 26.2 \\
\hline & $\mathrm{Fe}$ & 324 & 309 & 49 & 62.0 & 1350 & 197 & 68.8 & 1080 \\
\hline & $\mathrm{Hg}$ & 0.987 & 0.726 & 0.124 & 0.0817 & 3.01 & 0.920 & 0.0968 & 2.36 \\
\hline & $\mathrm{I}$ & 1144 & 943 & 149 & 29.0 & 3715 & 918 & 104 & 3619 \\
\hline & $\mathrm{K}$ & 6518 & 2304 & 443 & 3353 & 12222 & 6185 & 3395 & 10984 \\
\hline & $\mathrm{Mg}$ & 351 & 148 & 28 & 13.0 & 612 & 371 & 45.5 & 559 \\
\hline & $\mathrm{Mn}$ & 1.78 & 1.13 & 0.23 & 0.370 & 5.50 & 1.70 & 0.418 & 4.12 \\
\hline & $\mathrm{Na}$ & 11335 & 3597 & 705 & 7229 & 22381 & 10413 & 7277 & 19009 \\
\hline & $\mathrm{Rb}$ & 8.28 & 3.68 & 0.57 & 1.00 & 16.6 & 7.58 & 2.53 & 15.8 \\
\hline & $\mathrm{Sb}$ & 0.146 & 0.121 & 0.021 & 0.0102 & 0.425 & 0.103 & 0.0128 & 0.419 \\
\hline & $\mathrm{Sc}$ & 0.0130 & 0.0201 & 0.0040 & 0.0002 & 0.0910 & 0.0058 & 0.0002 & 0.0701 \\
\hline & $\mathrm{Se}$ & 3.09 & 2.59 & 0.44 & 0.994 & 12.6 & 2.37 & 1.16 & 12.1 \\
\hline & $\mathrm{Sr}$ & 2.43 & 2.73 & 0.49 & 0.80 & 13.7 & 1.64 & 0.80 & 10.6 \\
\hline & $\mathrm{Zn}$ & 119 & 53.1 & 8.2 & 47.0 & 270 & 105 & 49.1 & 246 \\
\hline
\end{tabular}

M - arithmetic mean, SD - standard deviation, SEM - standard error of mean, Min - minimum value, Max - maximum value, P 0.025 - percentile with 0.025 level, P 0.975 - percentile with 0.975 level

The comparison of our results with published data for $\mathrm{Ag}, \mathrm{Br}, \mathrm{Ca}, \mathrm{Cl}, \mathrm{Co}, \mathrm{Cr}, \mathrm{Cu}, \mathrm{Fe}, \mathrm{Hg}, \mathrm{I}, \mathrm{K}, \mathrm{Mg}, \mathrm{Mn}, \mathrm{Na}, \mathrm{Rb}, \mathrm{Sb}, \mathrm{Sc}, \mathrm{Se}, \mathrm{Sr}$, and $\mathrm{Zn}$ mass fraction in normal and goitrous thyroid [57-92] is shown in Table 4.

Table 4 Median, minimum and maximum value of means of twenty chemical element contents in the normal and goitrous thyroid according to data from the literature in comparison with our results ( $\mathrm{mg} / \mathrm{kg}$, dry mass basis)

\begin{tabular}{|c|c|c|c|c|}
\hline \multirow{2}{*}{$\begin{array}{l}\text { Tissue } \\
\text { Element }\end{array}$} & \multicolumn{3}{|c|}{ Published data [Reference] } & \multirow{2}{*}{$\begin{array}{l}\text { This work } \\
\text { Males and females } \\
\mathrm{M} \pm \mathrm{SD}\end{array}$} \\
\hline & $\begin{array}{l}\text { Median of } \\
\text { means } \\
(\mathrm{n})^{*}\end{array}$ & $\begin{array}{l}\text { Minimum of } \\
\text { means } \\
M \text { or } M \pm S D,(n)^{* *}\end{array}$ & $\begin{array}{l}\text { Maximum of } \\
\text { means } \\
M \text { or } M \pm S D,(n)^{* *}\end{array}$ & \\
\hline \multicolumn{5}{|l|}{ Normal } \\
\hline Ag & $0.21(12)$ & $0.000784(16)[57]$ & $1.20 \pm 1.24(105)[58]$ & $0.0151 \pm 0.0140$ \\
\hline $\mathrm{Br}$ & $18.1(11)$ & $5.12(44)[57]$ & $284 \pm 44(14)[59]$ & $14.9 \pm 10.9$ \\
\hline $\mathrm{Ca}$ & $1600(17)$ & $840 \pm 240(10)[60]$ & $3800 \pm 320(29)[60]$ & $1692 \pm 1022$ \\
\hline $\mathrm{Cl}$ & $6800(5)$ & $804 \pm 80(4)[61]$ & $8000(-)[62]$ & $3400 \pm 1452$ \\
\hline Co & $0.306(25)$ & $0.016(66)[63]$ & $70.4 \pm 40.8(14)[59]$ & $0.0399 \pm 0.0271$ \\
\hline $\mathrm{Cr}$ & $0.69(17)$ & $0.088(83)[64]$ & $24.8 \pm 2.4(4)[61]$ & $0.539 \pm 0.272$ \\
\hline
\end{tabular}


World Journal of Advanced Research and Reviews, 2021, 11(02), 130-146

\begin{tabular}{|c|c|c|c|c|}
\hline $\mathrm{Cu}$ & $5.94(61)$ & $0.16(83)[64]$ & $220 \pm 22(10)[61]$ & $4.23 \pm 1.52$ \\
\hline $\mathrm{Fe}$ & $252(21)$ & $56(120)[65]$ & $3360(25)[66]$ & $223 \pm 93$ \\
\hline $\mathrm{Hg}$ & $0.08(13)$ & $0.0008 \pm 0.0002(10)[60]$ & $396 \pm 40$ (4) [61] & $0.0421 \pm 0.0358$ \\
\hline I & $1888(95)$ & $159 \pm 8(23)[67]$ & $5772 \pm 2708(50)$ [68] & $1841 \pm 1027$ \\
\hline $\mathrm{K}$ & $4400(16)$ & $46.4 \pm 4.8(4)[61]$ & 6090 (17) [69] & $6071 \pm 2773$ \\
\hline $\mathrm{Mg}$ & 390 (16) & $3.5(-)[70]$ & $1520(20)[71]$ & $285 \pm 139$ \\
\hline $\mathrm{Mn}$ & $1.62(40)$ & $0.076(83)[64]$ & $69.2 \pm 7.2(4)[61]$ & $1.35 \pm 0.58$ \\
\hline $\mathrm{Na}$ & $8000(9)$ & $438(-)[72]$ & $10000 \pm 5000(11)[73]$ & $6702 \pm 1764$ \\
\hline $\mathrm{Rb}$ & $7.8(9)$ & $\leq 0.85$ (29) [60] & $294 \pm 191$ (14) [59] & $8.20 \pm 4.54$ \\
\hline $\mathrm{Sb}$ & $0.15(10)$ & $0.040 \pm 0.003(-)[72]$ & $\leq 12.4(-)[74]$ & $0.111 \pm 0.072$ \\
\hline $\mathrm{Sc}$ & $0.009(4)$ & $0.0018 \pm 0.0003$ (17) [75] & $0.014 \pm 0.005(10)[60]$ & $0.0046 \pm 0.0038$ \\
\hline $\mathrm{Se}$ & $2.32(21)$ & $0.436(40)[63]$ & $756 \pm 680$ (14) [59] & $2.32 \pm 1.29$ \\
\hline $\mathrm{Sr}$ & $0.73(9)$ & $0.55 \pm 0.26(21)[76]$ & $46.8 \pm 4.8(4)[61]$ & $4.55 \pm 3.22$ \\
\hline $\mathrm{Zn}$ & $110(56)$ & $2.1(-)[70]$ & $820 \pm 204(14)[59]$ & $105 \pm 40$ \\
\hline \multicolumn{5}{|c|}{ Goitrous } \\
\hline $\mathrm{Ag}$ & $0.210(4)$ & $0.098 \pm 0.042(19)[77]$ & 2.56 (167) [78] & $0.226 \pm 0.236$ \\
\hline $\mathrm{Br}$ & $480(5)$ & $9(5)[79]$ & 777 (1) [80] & $36.3 \pm 31.3$ \\
\hline $\mathrm{Ca}$ & $3168(8)$ & $600(1)[79]$ & 9200 (1) [79] & $1393 \pm 855$ \\
\hline $\mathrm{Cl}$ & - & - & - & $9117 \pm 3866$ \\
\hline Co & $0.67(12)$ & $0.110 \pm 0.003(64)[81]$ & $62.8 \pm 22.4$ (11) [59] & $0.0628 \pm 0.0287$ \\
\hline $\mathrm{Cr}$ & $3.66(5)$ & $0.72(51)$ [82] & $25.2(25)[66]$ & $0.849 \pm 0.834$ \\
\hline $\mathrm{Cu}$ & $6.52(8)$ & 1.04 (130) [63] & $120 \pm 52(11)$ [59] & $8.51 \pm 7.15$ \\
\hline $\mathrm{Fe}$ & $390(5)$ & $128 \pm 52(13)[83]$ & $4848 \pm 3056$ (11) [59] & $324 \pm 309$ \\
\hline $\mathrm{Hg}$ & - & - & - & $0.987 \pm 0.726$ \\
\hline I & $770(44)$ & $52(1)[84]$ & $2800(4)[85]$ & $1144 \pm 943$ \\
\hline K & $3725(4)$ & $276(75)[86]$ & $6030 \pm 620(-)[87]$ & $6518 \pm 2304$ \\
\hline $\mathrm{Mg}$ & $834(4)$ & $588 \pm 388(13)[83]$ & $1616(70)[71]$ & $351 \pm 148$ \\
\hline $\mathrm{Mn}$ & $2.64(21)$ & 0.352 (130) [63] & 34.9 (101) [88] & $1.78 \pm 1.13$ \\
\hline $\mathrm{Na}$ & $3360(1)$ & $3360(25)[66]$ & $3360(25)[66]$ & $11335 \pm 3597$ \\
\hline $\mathrm{Rb}$ & $7.5(2)$ & $7,0(10)[75]$ & $864 \pm 148$ (11) [59] & $8.28 \pm 3.68$ \\
\hline $\mathrm{Sb}$ & $0.63(1)$ & 0.15 (19) [89] & 1.10 (19) [89] & $0.146 \pm 0.121$ \\
\hline $\mathrm{Sc}$ & - & - & - & $0.0130 \pm 0.0201$ \\
\hline $\mathrm{Se}$ & $2.60(8)$ & $0.248(41)[63]$ & $174 \pm 116(11)$ [59] & $3.09 \pm 2.59$ \\
\hline $\mathrm{Sr}$ & $1.45(2)$ & $1.26(25)[66]$ & $1,64 \pm 1,44(51)[90]$ & $2.43 \pm 2.73$ \\
\hline $\mathrm{Zn}$ & $146(25)$ & 22.4 (130) [91] & $1236 \pm 560(2)[92]$ & $119 \pm 53.1$ \\
\hline
\end{tabular}


The ratios of means and the difference between mean values of $\mathrm{Ag}, \mathrm{Br}, \mathrm{Ca}, \mathrm{Cl}, \mathrm{Co}, \mathrm{Cr}, \mathrm{Cu}, \mathrm{Fe}, \mathrm{Hg}, \mathrm{I}, \mathrm{K}, \mathrm{Mg}, \mathrm{Mn}, \mathrm{Na}, \mathrm{Rb}, \mathrm{Sb}$, Sc, Se, Sr, and Zn mass fractions in normal and goitrous thyroid are presented in Table 5.

Table 5 Differences between mean values (M $\pm \mathrm{SEM}$ ) of $\mathrm{Ag}, \mathrm{Br}, \mathrm{Ca}, \mathrm{Cl}, \mathrm{Co}, \mathrm{Cr}, \mathrm{Cu}, \mathrm{Fe}, \mathrm{Hg}, \mathrm{I}, \mathrm{K}, \mathrm{Mg}, \mathrm{Mn}, \mathrm{Na}, \mathrm{Rb}, \mathrm{Sb}, \mathrm{Sc}, \mathrm{Se}, \mathrm{Sr}$, and $\mathrm{Zn}$ mass fraction ( $\mathrm{mg} / \mathrm{kg}$, dry mass basis) in normal thyroid and colloid nodular goiter

\begin{tabular}{|c|c|c|c|c|c|}
\hline \multirow[t]{2}{*}{ Element } & \multicolumn{4}{|c|}{ Thyroid tissue } & \multirow{2}{*}{$\begin{array}{c}\text { Ratio } \\
\text { Goiter } \\
\text { to Norm }\end{array}$} \\
\hline & $\begin{array}{l}\text { Norm } \\
n=105\end{array}$ & $\begin{array}{c}\text { Goiter } \\
\mathrm{n}=41\end{array}$ & $\begin{array}{c}\text { Student's t-test } \\
\qquad \leq \leq\end{array}$ & $\begin{array}{c}\text { U-test } \\
\quad p\end{array}$ & \\
\hline $\mathrm{Ag}$ & $0.0151 \pm 0.0016$ & $0.226 \pm 0.042$ & 0.000019 & $\leq 0.01$ & 15.0 \\
\hline $\mathrm{Br}$ & $14.9 \pm 1.2$ & $36.3 \pm 7.0$ & 0.0067 & $\leq 0.01$ & 2.44 \\
\hline $\mathrm{Ca}$ & $1711 \pm 109$ & $1393 \pm 168$ & 0.118 & $>0.05$ & 0.81 \\
\hline $\mathrm{Cl}$ & $3400 \pm 174$ & $9117 \pm 1223$ & 0.0011 & $\leq 0.01$ & 2.68 \\
\hline Co & $0.0399 \pm 0.0030$ & $0.0628 \pm 0.0050$ & 0.00023 & $\leq 0.01$ & 1.57 \\
\hline $\mathrm{Cr}$ & $0.539 \pm 0.032$ & $0.849 \pm 0.150$ & 0.051 & $>0.05$ & 1.58 \\
\hline $\mathrm{Cu}$ & $4.23 \pm 0.18$ & $8.51 \pm 1.60$ & 0.015 & $\leq 0.01$ & 2.01 \\
\hline $\mathrm{Fe}$ & $223 \pm 10$ & $324 \pm 49$ & 0.049 & $\leq 0.01$ & 1.45 \\
\hline $\mathrm{Hg}$ & $0.0421 \pm 0.0041$ & $0.987 \pm 0.124$ & 0.0000000098 & $\leq 0.01$ & 23.4 \\
\hline I & $1841 \pm 107$ & $1144 \pm 149$ & 0.00028 & $\leq 0.01$ & 0.62 \\
\hline $\mathrm{K}$ & $6071 \pm 306$ & $6518 \pm 443$ & 0.410 & $>0.05$ & 1.07 \\
\hline $\mathrm{Mg}$ & $285 \pm 17$ & $351 \pm 28$ & 0.049 & $\leq 0.01$ & 1.23 \\
\hline $\mathrm{Mn}$ & $1.35 \pm 0.07$ & $1.78 \pm 0.23$ & 0.079 & $>0.05$ & 1.32 \\
\hline $\mathrm{Na}$ & $6702 \pm 178$ & $11335 \pm 705$ & 0.00000066 & $\leq 0.01$ & 1.69 \\
\hline $\mathrm{Rb}$ & $8.16 \pm 0.49$ & $8.28 \pm 0.57$ & 0.874 & $>0.05$ & 1.01 \\
\hline $\mathrm{Sb}$ & $0.111 \pm 0.008$ & $0.146 \pm 0.021$ & 0.119 & $>0.05$ & 1.32 \\
\hline Sc & $0.0046 \pm 0.0008$ & $0.0130 \pm 0.0040$ & 0.037 & $\leq 0.01$ & 2.83 \\
\hline $\mathrm{Se}$ & $2.32 \pm 0.14$ & $3.09 \pm 0.44$ & 0.105 & $>0.05$ & 1.33 \\
\hline $\mathrm{Sr}$ & $4.55 \pm 0.37$ & $2.43 \pm 0.49$ & 0.0011 & $\leq 0.01$ & 0.53 \\
\hline $\mathrm{Zn}$ & $105.1 \pm 4.3$ & $119 \pm 8.2$ & 0.148 & $>0.05$ & 1.13 \\
\hline
\end{tabular}

\section{Discussion}

\subsection{Precision and accuracy of results}

A good agreement of our results for the $\mathrm{Ag}, \mathrm{Br}, \mathrm{Ca}, \mathrm{Cl}, \mathrm{Co}, \mathrm{Cr}, \mathrm{Cu}, \mathrm{Fe}, \mathrm{Hg}, \mathrm{I}, \mathrm{K}, \mathrm{Mg}, \mathrm{Mn}, \mathrm{Na}, \mathrm{Rb}, \mathrm{Sb}, \mathrm{Sc}$, Se, $\mathrm{Sr}$, and $\mathrm{Zn}$ mass fractions with the certified values of CRM IAEA H-4 and CRM IAEA HH-1 (Table 1) as well as the similarity of the means of the $\mathrm{Br}, \mathrm{Fe}, \mathrm{Rb}$, and $\mathrm{Zn}$ mass fractions in the normal human thyroid determined by both EDXRF and INAA methods (Table 2) demonstrates an acceptable precision and accuracy of the results obtained in the study and presented in Tables 3-5.

The mean values and all selected statistical parameters were calculated for twenty $\mathrm{ChE}(\mathrm{Ag}, \mathrm{Br}, \mathrm{Ca}, \mathrm{Cl}, \mathrm{Co}, \mathrm{Cr}, \mathrm{Cu}, \mathrm{Fe}, \mathrm{Hg}$, $\mathrm{I}, \mathrm{K}, \mathrm{Mg}, \mathrm{Mn}, \mathrm{Na}, \mathrm{Rb}, \mathrm{Sb}, \mathrm{Sc}, \mathrm{Se}, \mathrm{Sr}$, and $\mathrm{Zn}$ ) mass fractions (Table 3). The mass fraction of $\mathrm{Ag}, \mathrm{Br}, \mathrm{Ca}, \mathrm{Cl}, \mathrm{Co}, \mathrm{Cr}, \mathrm{Cu}, \mathrm{Fe}, \mathrm{Hg}$, $\mathrm{I}, \mathrm{K}, \mathrm{Mg}, \mathrm{Mn}, \mathrm{Na}, \mathrm{Rb}, \mathrm{Sb}, \mathrm{Sc}$, Se, Sr, and Zn were measured in all, or a major portion of normal and goitrous tissue samples. 


\subsection{Comparison with published data}

Values obtained for $\mathrm{Br}, \mathrm{Ca}, \mathrm{Cl}, \mathrm{Cr}, \mathrm{Cu}, \mathrm{Fe}, \mathrm{Hg}, \mathrm{I}, \mathrm{K}, \mathrm{Mg}, \mathrm{Mn}, \mathrm{Na}, \mathrm{Rb}, \mathrm{Sb}$, Sc, Se, and $\mathrm{Zn}$ contents in the normal human thyroid (Table 4) agree well with median of mean values reported by other researches [57-92]. The obtained means for Ag and Co were almost one order of magnitude lower whereas mean for Sr was 6.2 times higher median of previously reported means, but, nevertheless, inside the range of means (Table 4). A number of values for ChE mass fractions were not expressed on a dry mass basis by the authors of the cited references. However, we calculated these values using published data for water (75\%) [93] and ash (4.16\% on dry mass basis) [94] contents in thyroid of adults.

Data cited in Table 4 for normal thyroid also includes samples obtained from patients who died from different nonendocrine diseases. In our previous study it was shown that some non-endocrine diseases can effect on ChE contents in thyroid [24]. Moreover, in many studies the "normal" thyroid means a visually non-affected tissue adjacent to benign or malignant thyroidal nodules. However, there are no data on a comparison between the ChE contents in such kind of samples and those in thyroid of healthy persons, which permits to confirm their identity.

In goitrous thyroid (Table 4) our results were comparable with published data for $\mathrm{Ag}, \mathrm{Ca}, \mathrm{Cu}, \mathrm{Fe}, \mathrm{I}, \mathrm{Mn}, \mathrm{Rb}, \mathrm{Se}$, and $\mathrm{Zn}$ contents. The obtained means for $\mathrm{Br}$ and Co were approximately one order of magnitude lower median of previously reported means. The obtained mean for $\mathrm{Br}$ was inside the range of reported means, whereas the obtained mean for Co was lower the minimal mean of range (Table 4). The obtained means for $\mathrm{Cr}, \mathrm{Mg}$, and Sb were 4.3, 2.4, and 4.3 times, respectively, lower the median of previously reported result and also lower the minimal level of the range of these means (Table 4). At the same time, mean for $\mathrm{K}, \mathrm{Na}$, and $\mathrm{Sr}$ was 1.7, 3.4, and 1.7 times, respectively, higher median of previously reported means and also higher the upper level of the range of these means (Table 4). No published data referring $\mathrm{Cl}, \mathrm{Hg}$, and $\mathrm{Sc}$ contents of goitrous thyroid tissue were found.

The range of means of $\mathrm{Ag}, \mathrm{Br}, \mathrm{Ca}, \mathrm{Cl}, \mathrm{Co}, \mathrm{Cr}, \mathrm{Cu}, \mathrm{Fe}, \mathrm{Hg}, \mathrm{I}, \mathrm{K}, \mathrm{Mg}, \mathrm{Mn}, \mathrm{Na}, \mathrm{Rb}, \mathrm{Sb}, \mathrm{Sc}, \mathrm{Se}, \mathrm{Sr}$, and $\mathrm{Zn}$ level reported in the literature for normal and for goitrous thyroid vary widely (Table 4). This can be explained by a dependence of ChE content on many factors, including "normality" of thyroid samples (see above), the region of the thyroid, from which the sample was taken, age, gender, ethnicity, mass of the gland, and the goiter stage. Not all these factors were strictly controlled in cited studies. However, in our opinion, the leading causes of inter-observer variability can be attributed to the accuracy of the analytical techniques, sample preparation methods, and inability of taking uniform samples from the affected tissues. It was insufficient quality control of results in these studies. In many scientific reports, tissue samples were ashed or dried at high temperature for many hours. In other cases, thyroid samples were treated with solvents (distilled water, ethanol, formalin etc). There is evidence that during ashing, drying and digestion at high temperature some quantities of certain $\mathrm{ChE}$ are lost as a result of this treatment. That concerns not only such volatile halogen as Br, but also other ChE investigated in the study $[49,95,96]$.

\subsection{Effect of goitrous transformation on ChE contents}

From Table 5, it is observed that in goitrous tissue the mass fraction of $\mathrm{Ag}, \mathrm{Br}, \mathrm{Cl}, \mathrm{Cu}, \mathrm{Hg}$, and Sc are approximately 15.0 , 2.4, 2.7, 2.0, 23.4 and 2.8 times, respectively, higher and also mass fractions of $\mathrm{Co}, \mathrm{Fe}, \mathrm{Mg}$, and $\mathrm{Na}$ are almost in 57\%, $45 \%, 23 \%$, and 69\%, respectively, significantly higher than in normal tissues of the thyroid. In contrast, the mass fractions of I and $\mathrm{Sr}$ are $38 \%$ and $47 \%$, respectively, lower. Thus, if we accept the ChE contents in thyroid glands in the control group as a norm, we have to conclude that with a goitrous transformation the levels of $\mathrm{Ag}, \mathrm{Br}, \mathrm{Cl}, \mathrm{Co}, \mathrm{Cu}, \mathrm{Fe}, \mathrm{Hg}$, $\mathrm{Mg}, \mathrm{Na}$, and Sc in thyroid tissue significantly increased whereas the levels of I and Sr decrease.

\subsection{Role of ChE in goitrous transformation of the thyroid}

Characteristically, elevated or reduced levels of ChE observed in goitrous tissues are discussed in terms of their potential role in the initiation and promotion of thyroid goiter. In other words, using the low or high levels of the ChE in goitrous tissues researchers try to determine the goitrogenic role of the deficiency or excess of each ChE in investigated organ. In our opinion, abnormal levels of many ChE in goiter could be and cause, and also effect of goitrous transformation. From the results of such kind studies, it is not always possible to decide whether the measured decrease or increase in ChE level in pathologically altered tissue is the reason for alterations or vice versa.

\subsubsection{Silver}

$\mathrm{Ag}$ is a ChE with no recognized trace metal value in the human body [97]. Ag in metal form and inorganic Ag compounds ionize in the presence of water, body fluids or tissue exudates. The silver ion $\mathrm{Ag}^{+}$is biologically active and readily interacts with proteins, amino acid residues, free anions and receptors on mammalian and eukaryotic cell membranes [98]. Besides such the adverse effects of chronic exposure to Ag as a permanent bluish-gray discoloration of the skin (argyria) or eyes (argyrosis), exposure to soluble Ag compounds may produce other toxic effects, including liver and 
kidney damage, irritation of the eyes, skin, respiratory, and intestinal tract, and changes in blood cells [99]. More detailed knowledge of the Ag toxicity can lead to a better understanding of the impact on human health, including thyroid function.

\subsubsection{Bromine}

This is one of the most abundant and ubiquitous of the recognized ChE in the biosphere. Inorganic bromide is the ionic form of bromine which exerts therapeutic as well as toxic effects. An enhanced intake of bromide could interfere with the metabolism of iodine at the whole-body level. In the thyroid gland the biological behavior of bromide is more similar to the biological behavior of iodide [100].

In our previous studies, we found a significant age-related increase of $\mathrm{Br}$ content in human thyroid [25-28,31,32]. Therefore, a goitrogenic and, probably, carcinogenic effect of excessive $\mathrm{Br}$ levels in the thyroid of old females was assumed. On the one hand, elevated levels of Br in NG tissues, observed in the present study, supports this conclusion. But, on the other hand, bromide compounds, especially potassium bromide (KBr), sodium bromide ( $\mathrm{NaBr}$ ), and ammonium bromide $\left(\mathrm{NH}_{4} \mathrm{Br}\right.$ ), are frequently used as sedatives in Russia [101]. It may be the reason for elevated levels of $\mathrm{Br}$ in specimens of patients with NG.

\subsubsection{Chlorine}

$\mathrm{Cl}$ is a ubiquitous, extracellular electrolyte essential to more than one metabolic pathway. Cl exists in the form of chloride in the human body. In the body, it is mostly present as sodium chloride. Therefore, as usual, there is a correlation between $\mathrm{Na}$ and $\mathrm{Cl}$ contents in tissues and fluids of human body. It is well known that $\mathrm{Cl}$ mass fractions in samples depend mainly on the extracellular water volume, including the blood volumes, in tissues [102]. Colloid is the extracellular liquid. Thus, it is possible to speculate that colloid NG are characterized by an increase of the mean value of the $\mathrm{Cl}$ mass fraction because the level of colloid is higher than that in normal thyroid tissue.

\subsubsection{Cobalt}

Health effects of high Co occupational, environmental, dietary and medical exposure are characterized by a complex clinical syndrome, mainly including neurological, cardiovascular and endocrine deficits, including hypothyroidism and goiter $[103,104]$. Co is genotoxic and carcinogenic, mainly caused by oxidative DNA damage by reactive oxygen species, perhaps combined with inhibition of DNA repair [105]. In our previous studies it was found a significant age-related increase of Co content in female thyroid [29]. Therefore, a goitrogenic and, probably, carcinogenic effect of excessive Co level in the thyroid of old females was assumed. Elevated level of Co in NG tissues, observed in the present study, supports this conclusion.

\subsubsection{Copper}

This is a ubiquitous ChE in the human body which plays many roles at different levels. Various Cu-enzymes (such as amine oxidase, ceruloplasmin, cytochrome-c oxidase, dopamine-monooxygenase, extracellular superoxide dismutase, lysyl oxidase, peptidylglycineamidating monoxygenase, $\mathrm{Cu} / \mathrm{Zn}$ superoxide dismutase, and tyrosinase) mediate the effects of $\mathrm{Cu}$ deficiency or excess. $\mathrm{Cu}$ excess can have severe negative impacts. $\mathrm{Cu}$ generates oxygen radicals and many investigators have hypothesized that excess copper might cause cellular injury via an oxidative pathway, giving rise to enhanced lipid peroxidation, thiol oxidation, and, ultimately, DNA damage [106-108]. Thus, $\mathrm{Cu}$ accumulation in thyroid parenchyma with age may be involved in oxidative stress, dwindling gland function, and increasing risk of goiter or cancer $[25,26,33,34]$. The significantly elevated level of $\mathrm{Cu}$ in thyroid goitrous tissue, observed in the present study, supports this speculation. However, an overall comprehension of $\mathrm{Cu}$ homeostasis and physiology, which is not yet acquired, is mandatory to establish $\mathrm{Cu}$ exact role in the thyroid goiter etiology and metabolism.

Representative literature data on the $\mathrm{Cu}$ content in NG are limited. Moreover, there are great contradictions in the results between the reported studies. For example, Kolomiitseva [109] and Fal'fushins'ka at al.[110] reported that the content of $\mathrm{Cu}$ was 1.3 and 2 times, respectively, higher in goitrous tissues compared with that in normal thyroid. These data are in good agreement with our results. The completely opposite results were demonstrated by Błazewicz et al [81] and Stojsavljević et al [63]. They found that the content of Cu was reduced in NG.

\subsubsection{Iron}

It is well known that Fe as $\mathrm{ChE}$ is involved in many very important functions and biochemical reactions of human body. Fe metabolism is therefore very carefully regulated at both a systemic and cellular level $[111,112]$. Under the impact of age and multiple environmental factors the Fe metabolism may become dysregulated with attendant accumulation of 
this metal excess in tissues and organs, including thyroid [25,26,29-34]. Most experimental and epidemiological data support the hypothesis that Fe overload is a risk factor for benign and malignant tumors [113]. This goitrogenic and oncogenic effect could be explained by an overproduction of ROS and free radicals [114].

\subsubsection{Mercury}

$\mathrm{Hg}$ is one of the most dangerous environmental pollutants [115]. The growing use of this metal in diverse areas of industry has resulted in a significant increase of environment contamination and episodes of human intoxication. $\mathrm{Hg}$ damages the central nervous system and has irreparable effects on the kidneys [116]. Hg may also harm a developing fetus and decrease fertility in men and women [117]. Besides these effects, $\mathrm{Hg}$ has been classified as certain or probable carcinogen by the International Agency for Research on Cancer [118]. For example, in Hg polluted area thyroid cancer incidence was almost 2 times higher than in in adjacent control areas [119].

Negative effects of Hg are due to the interference of this metal in cellular signaling pathways and protein synthesis during the period of development. Since it bonds chemically with the sulfur hydride groups of proteins, it causes damage to the cell membrane and decreases the amount of RNA [120]. Moreover, it was shown that Hg may be involved in four main processes that lead to genotoxicity: generation of free radicals and oxidative stress, action on microtubules, influence on DNA repair mechanisms and direct interaction with DNA molecules [121].

\subsubsection{Iodine}

Compared to other soft tissues, the human thyroid gland has higher levels of I, because this element plays an important role in its normal functions, through the production of thyroid hormones (thyroxin and triiodothyronine) which are essential for cellular oxidation, growth, reproduction, and the activity of the central and autonomic nervous system. The I deficiency is one of the main causes of NG transformation, which leads to a significant reduction in I content associated with functional characteristics of the human thyroid tissue.

\subsubsection{Magnesium}

Mg is abundant in the human body. This ChE is essential for the functions of more than 300 enzymes (e.g. alkaline phosphatases, ATP-ases, phosphokinases, the oxidative phosphorylation pathway). It plays a crucial role in many cell functions such as energy metabolism, protein and DNA syntheses, and cytoskeleton activation. Moreover, Mg plays a central role in determining the clinical picture associated with thyroid disease [122]. Little elevated Mg level in NG tissues possibly caused by the high Mg requirement of growing goitrous cells [123].

\subsubsection{Sodium}

$\mathrm{Na}$ is mainly an extracellular electrolyte and its elevated level in goitrous thyroid might link with a high content of colloid (see Chlorine).

\subsubsection{Scandium}

Sc is a rare earth ChE. Information about its physiological role is very limited. However, toxic effects concerning Sc propensity to displace calcium in many biochemical events and its carcinogenic potential have been reported $[124,125]$.

\subsubsection{Strontium}

Obtained results for $\mathrm{Sr}$ content in NG agree well with data reported in old studies $[66,90]$. The role of $\mathrm{Sr}$ in the thyroid function and goitrogenesis is unknown. We can't explain why the Sr level in goitrous tissues is almost twice lower than in normal thyroid. Interestingly remark, however, that very similar result of reduced $\mathrm{Sr}$ content was indicated in thyroid adenoma [61].

Our findings show that mass fraction of $\mathrm{Ag}, \mathrm{Br}, \mathrm{Cl}, \mathrm{Co}, \mathrm{Cu}, \mathrm{Fe}, \mathrm{Hg}, \mathrm{I}, \mathrm{Mg}, \mathrm{Na}, \mathrm{Sc}$ and $\mathrm{Sr}$ are significantly different in $\mathrm{NG}$ as compared to normal thyroid tissues (Table 5). Thus, it is plausible to assume that levels of these ChE in thyroid tissue can be used as NG markers. However, this subjects needs in additional studies.

\section{Limitations}

This study has several limitations. Firstly, analytical techniques employed in this study measure only twenty $\mathrm{ChE}$ (Ag, $\mathrm{Br}, \mathrm{Ca}, \mathrm{Cl}, \mathrm{Co}, \mathrm{Cr}, \mathrm{Cu}, \mathrm{Fe}, \mathrm{Hg}, \mathrm{I}, \mathrm{K}, \mathrm{Mg}, \mathrm{Mn}, \mathrm{Na}, \mathrm{Rb}, \mathrm{Sb}, \mathrm{Sc}, \mathrm{Se}, \mathrm{Sr}$, and $\mathrm{Zn}$ ) mass fractions. Future studies should be directed toward using other analytical methods which will extend the list of ChE investigated in normal and goitrous thyroid. Secondly, the sample size of NG group was relatively small. It was not allow us to carry out the investigations of chemical 
element contents in NG group using differentials like gender, histological types of goiter, stage of disease, and dietary habits of healthy persons and patients with NG. Lastly, generalization of our results may be limited to Russian population. Despite these limitations, this study provides evidence on goiter-specific tissue $\mathrm{Ag}, \mathrm{Br}, \mathrm{Cl}, \mathrm{Co}, \mathrm{Cu}, \mathrm{Fe}, \mathrm{Hg}, \mathrm{I}$, $\mathrm{Mg}, \mathrm{Na}, \mathrm{Sc}$, and Sr level alteration and shows the necessity to continue ChE research of NG.

\section{Conclusion}

In this work, ChE measurements were carried out in the tissue samples of normal thyroid and NG of thyroid using three non-destructive instrumental analytical methods: EDXRF, INAA-SLR, and INAA-LLR. It was shown that the combination of these methods is an adequate analytical tool for the non-destructive determination of $\mathrm{Ag}, \mathrm{Br}, \mathrm{Ca}, \mathrm{Cl}, \mathrm{Co}, \mathrm{Cr}, \mathrm{Cu}, \mathrm{Fe}, \mathrm{Hg}$, $\mathrm{I}, \mathrm{K}, \mathrm{Mg}, \mathrm{Mn}, \mathrm{Na}, \mathrm{Rb}, \mathrm{Sb}, \mathrm{Sc}$, Se, Sr, and $\mathrm{Zn}$ content in the tissue samples of human thyroid, including needle-biopsy cores. It was observed that in goitrous tissues content of $\mathrm{Ag}, \mathrm{Br}, \mathrm{Cl}, \mathrm{Co}, \mathrm{Cu}, \mathrm{Fe}, \mathrm{Hg}, \mathrm{Mg}$, $\mathrm{Na}$, and $\mathrm{Sc}$ significantly increased whereas the levels of I and $\mathrm{Sr}$ decrease in a comparison with the normal thyroid tissues. In our opinion, the increase in levels of $\mathrm{Ag}, \mathrm{Br}, \mathrm{Cl}, \mathrm{Co}, \mathrm{Cu}, \mathrm{Fe}, \mathrm{Hg}, \mathrm{Mg}, \mathrm{Na}$, and $\mathrm{Sc}$, as well as the decrease in levels of I and $\mathrm{Sr}$ in goitrous tissue might demonstrate an involvement of these $\mathrm{ChE}$ in etiology and pathogenesis of NG. It was supposed that the changes in levels $\mathrm{Ag}$, $\mathrm{Br}$, $\mathrm{Cl}$, $\mathrm{Co}, \mathrm{Cu}, \mathrm{Fe}, \mathrm{Hg}, \mathrm{I}, \mathrm{Mg}, \mathrm{Na}$, Sc and $\mathrm{Sr}$ in thyroid tissue can be used as NG markers.

\section{Compliance with ethical standards}

\section{Acknowledgments}

The author is extremely grateful to Profs. B.M. Vtyurin and V.S. Medvedev, Medical Radiological Research Center, Obninsk, as well as to Dr. Yu. Choporov, Head of the Forensic Medicine Department of City Hospital, Obninsk, for supplying thyroid samples.

\section{Disclosure of conflict of interest}

The author declares that he has no competing interests.

\section{Statement of ethical approval}

All studies were approved by the Ethical Committees of the Medical Radiological Research Centre (MRRC), Obninsk. All the procedures performed in studies involving human participants were in accordance with the ethical standards of the institutional and/or national research committee and with the 1964 Helsinki declaration and its later amendments, or with comparable ethical standards.

\section{Statement of informed consent}

Informed consent was obtained from all individual participants included in the study.

\section{References}

[1] Carlé A, Krejbjerg A, Laurberg P. Epidemiology of nodular goitre. Influence of iodine intake. Best Pract Res Clin Endocrinol Metab. 2014; 28(4): 465-79.

[2] Kant R, Davis A, Verma V. Thyroid nodules: Advances in evaluation and management. Am Fam Physician. 2020; 102(5): 298-304.

[3] Hoang VT, Trinh CT. A review of the pathology, diagnosis and management of colloid goitre. Eur Endocrinol. 2020; 16(2): 131-5.

[4] Derwahl M, Studer H. Multinodular goitre: 'much more to it than simply iodine deficiency'. Baillieres Best Pract Res Clin Endocrinol Metab. 2000; 14(4): 577-600.

[5] Zaichick V. Iodine excess and thyroid cancer. J Trace Elem Exp Med. 1998; 11(4): 508-9.

[6] Zaichick V, Iljina T. Dietary iodine supplementation effect on the rat thyroid 131I blastomogenic action. In: Die Bedentung der Mengen- und Spurenelemente. 18. Arbeitstangung. Jena: Friedrich-Schiller-Universitat. 1998; 294-306. 
[7] Kim S, Kwon YS, Kim JY, Hong KH, Park YK. Association between Iodine Nutrition Status and Thyroid DiseaseRelated Hormone in Korean Adults: Korean National Health and Nutrition Examination Survey VI (2013-2015). Nutrients. 2019; 11(11): 27-57.

[8] Vargas-Uricoechea P, Pinzón-Fernández MV, Bastidas-Sánchez BE, Jojoa-Tobar E, Ramírez-Bejarano LE, MurilloPalacios J. Iodine Status in the Colombian Population and the Impact of Universal Salt Iodization: A Double-Edged Sword? J Nutr Metab. 2019; 6239243.

[9] Stojsavljević A, Rovčanin B, Krstić D, Jagodić J, Borković-Mitić S, Paunović I, Živaljević V, Mitić B, GavrovićJankulović M, Manojlović D. Cadmium as main endocrine disruptor in papillary thyroid carcinoma and the significance of Cd/Se ratio for thyroid tissue pathophysiology. J Trace Elem Med Biol. 2019; 55: 190-5.

[10] Fahim YA, Sharaf NE, Hasani IW, Ragab EA, Abdelhakim HK. Assessment of Thyroid Function and Oxidative Stress State in Foundry Workers Exposed to Lead. J Health Pollut. 2020; 10(27): 200903.

[11] Liu M, Song J, Jiang Y, Lin Y, Peng J, Liang H, Wang C, Jiang J, Liu X, Wei W, Peng J, Liu S, Li Y, Xu N, Zhou D, Zhang Q, Zhang J. A case-control study on the association of mineral elements exposure and thyroid tumor and goiter. Ecotoxicol Environ Saf. 2021; 208: 111615.

[12] Zaichick V. Medical elementology as a new scientific discipline. J Radioanal Nucl Chem. 2006; 269: 303-9.

[13] Moncayo R, Moncayo H. A post-publication analysis of the idealized upper reference value of $2.5 \mathrm{mIU} / \mathrm{L}$ for TSH: Time to support the thyroid axis with magnesium and iron especially in the setting of reproduction medicine. BBA Clin. 2017; 7: 115-9.

[14] Beyersmann D, Hartwig A. Carcinogenic metal compounds: recent insight into molecular and cellular mechanisms. Arch Toxicol. 2008; 82(8): 493-512.

[15] Martinez-Zamudio R, Ha HC. Environmental epigenetics in metal exposure. Epigenetics. 2011; 6(7): 820-7.

[16] Ză̌chik VE, Raibukhin YuS, Melnik AD, Cherkashin VI. Neutron-activation analysis in the study of the behavior of iodine in the organism. Med Radiol (Mosk). 1970; 15(1): 33-6.

[17] Zaĭchik VE, Matveenko EG, Vtiurin BM, Medvedev VS. Intrathyroid iodine in the diagnosis of thyroid cancer. Vopr Onkol. 1982; 28(3): 18-24.

[18] Zaichick V, Tsyb AF, Vtyurin BM. Trace elements and thyroid cancer. Analyst. 1995; 120(3): 817-21.

[19] Zaichick VYe, Choporov YuYa. Determination of the natural level of human intra-thyroid iodine by instrumental neutron activation analysis. J Radioanal Nucl Chem. 1996; 207(1): 153-61.

[20] Zaichick V. In vivo and in vitro application of energy-dispersive XRF in clinical investigations: experience and the future. J Trace Elem Exp Med. 1998; 11(4): 509-10.

[21] Zaichick V, Zaichick S. Energy-dispersive X-ray fluorescence of iodine in thyroid puncture biopsy specimens. J Trace Microprobe Tech. 1999; 17(2): 219-32.

[22] Zaichick V. Relevance of, and potentiality for in vivo intrathyroidal iodine determination. Ann N Y Acad Sci. 2000; 904: 630-2.

[23] Zaichick V, Zaichick S. Normal human intrathyroidal iodine. Sci Total Environ. 1997; 206(1): 39-56.

[24] Zaichick V. Human intrathyroidal iodine in health and non-thyroidal disease. In: New aspects of trace element research (Eds: M.Abdulla, M.Bost, S.Gamon, P.Arnaud, G.Chazot). London: Smith-Gordon; and Tokyo:Nishimura. 1999; 114-9.

[25] Zaichick V, Zaichick S. Age-related changes of some trace element contents in intact thyroid of females investigated by energy dispersive X-ray fluorescent analysis. Trends Geriatr Healthc. 2017; 1(1): 31-38.

[26] Zaichick V, Zaichick S. Age-related changes of some trace element contents in intact thyroid of males investigated by energy dispersive X-ray fluorescent analysis. MOJ Gerontol Ger. 2017; 1(5): 00028.

[27] Zaichick V, Zaichick S. Age-related changes of $\mathrm{Br}, \mathrm{Ca}, \mathrm{Cl}, \mathrm{I}, \mathrm{K}, \mathrm{Mg}$, $\mathrm{Mn}$, and $\mathrm{Na}$ contents in intact thyroid of females investigated by neutron activation analysis. Curr Updates Aging. 2017; 1: 5.1.

[28] Zaichick V, Zaichick S. Age-related changes of $\mathrm{Br}, \mathrm{Ca}, \mathrm{Cl}, \mathrm{I}, \mathrm{K}, \mathrm{Mg}, \mathrm{Mn}$, and $\mathrm{Na}$ contents in intact thyroid of males investigated by neutron activation analysis. J Aging Age Relat Dis. 2017; 1(1): 1002.

[29] Zaichick V, Zaichick S. Age-related changes of Ag, Co, Cr, Fe, Hg, Rb, Sb, Sc, Se, and Zn contents in intact thyroid of females investigated by neutron activation analysis. J Gerontol Geriatr Med. 2017; 3: 015. 
[30] Zaichick V, Zaichick S. Age-related changes of Ag, Co, Cr, Fe, Hg, Rb, Sb, Sc, Se, and Zn contents in intact thyroid of males investigated by neutron activation analysis. Curr Trends Biomedical Eng Biosci. 2017; 4(4): 555644.

[31] Zaichick V, Zaichick S. Effect of age on chemical element contents in female thyroid investigated by some nuclear analytical methods. MicroMedicine. 2018; 6(1): 47-61.

[32] Zaichick V, Zaichick S. Neutron activation and X-ray fluorescent analysis in study of association between age and chemical element contents in thyroid of males. Op Acc J Bio Eng Bio Sci. 2018; 2(4): 202-12.

[33] Zaichick V, Zaichick S. Variation with age of chemical element contents in females' thyroids investigated by neutron activation analysis and inductively coupled plasma atomic emission spectrometry. J Biochem Analyt Stud. 2018; 3(1): 1-10.

[34] Zaichick V, Zaichick S. Association between Age and Twenty Chemical Element Contents in Intact Thyroid of Males. SM Gerontol Geriatr Res. 2018; 2(1): 1014.

[35] Zaichick V, Zaichick S. Associations between age and 50 trace element contents and relationships in intact thyroid of males. Aging Clin Exp Res. 2018; 30(9): 1059-70.

[36] Zaichick V, Zaichick S. Possible role of inadequate quantities of intra-thyroidal bromine, rubidium and zinc in the etiology of female subclinical hypothyroidism. EC Gynaecology. 2018; 7(3): 107-15.

[37] Zaichick V, Zaichick S. Possible role of inadequate quantities of intra-thyroidal bromine, calcium and magnesium in the etiology of female subclinical hypothyroidism. Int Gyn and Women's Health. 2018; 1(3): IGWHC.MS.ID.000113.

[38] Zaichick V, Zaichick S. Possible role of inadequate quantities of intra-thyroidal cobalt, rubidium and zinc in the etiology of female subclinical hypothyroidism. Womens Health Sci J. 2018; 2(1): 000108.

[39] Zaichick V, Zaichick S. Association between female subclinical hypothyroidism and inadequate quantities of some intra-thyroidal chemical elements investigated by X-ray fluorescence and neutron activation analysis. Gynaecology and Perinatology. 2018; 2(4): 340-55.

[40] Zaichick V, Zaichick S. Investigation of association between the high risk of female subclinical hypothyroidism and inadequate quantities of twenty intra-thyroidal chemical elements. Clin Res: Gynecol Obstet. 2018; 1(1): 118.

[41] Zaichick V, Zaichick S. Investigation of association between the high risk of female subclinical hypothyroidism and inadequate quantities of intra-thyroidal trace elements using neutron activation and inductively coupled plasma mass spectrometry. Acta Scientific Medical Sciences. 2018; 2(9): 23-37.

[42] Zaichick V, Zaichick S. Trace element contents in thyroid cancer investigated by energy dispersive X-ray fluorescent analysis. American Journal of Cancer Research and Reviews. 2018; 2: 5.

[43] Zaichick V, Zaichick S. Trace element contents in thyroid cancer investigated by instrumental neutron activation analysis. J Oncol Res. 2018; 2(1): 1-13.

[44] Zaichick V, Zaichick S. Variation in selected chemical element contents associated with malignant tumors of human thyroid gland. Cancer Studies. 2018; 2(1): 2.

[45] Zaichick V, Zaichick S. Twenty chemical element contents in normal and cancerous thyroid. Int J Hematol Blo Dis. 2018; 3(2): 1-13.

[46] Zaichick V, Zaichick S. Levels of chemical element contents in thyroid as potential biomarkers for cancer diagnosis (a preliminary study). J Cancer Metastasis Treat. 2018; 4: 60.

[47] Zaichick V, Zaichick S. Fifty trace element contents in normal and cancerous thyroid. Acta Scientific Cancer Biology. 2018; 2(8): 21-38.

[48] Zaichick V, Zaichick S. Instrumental effect on the contamination of biomedical samples in the course of sampling. The Journal of Analytical Chemistry. 1996; 51(12): 1200-5.

[49] Zaichick V, Tsislyak YuV. A simple device for biosample lyophilic drying. Lab Delo. 1978; 2: 109-10.

[50] Zaichick S, Zaichick V. The Br, Fe, Rb, Sr, and Zn contents and interrelation in intact and morphologic normal prostate tissue of adult men investigated by energy-dispersive X-ray fluorescent analysis. X-Ray Spectrom. 2011; 40(6): 464-9. 
[51] Zaichick S, Zaichick V. The effect of age and gender on 37 chemical element contents in scalp hair of healthy humans. Biol Trace Elem Re. 2010; 134(1): 41-54.

[52] Zaichick S, Zaichick V. INAA application in the age dynamics assessment of $\mathrm{Br}, \mathrm{Ca}, \mathrm{Cl}, \mathrm{K}, \mathrm{Mg}$, $\mathrm{Mn}$, and $\mathrm{Na}$ content in the normal human prostate. J Radioanal Nucl Chem. 2011; 288(1): 197-202.

[53] Zaichick V, Zaichick S. The effect of age on $\mathrm{Br}, \mathrm{Ca}, \mathrm{Cl}, \mathrm{K}, \mathrm{Mg}, \mathrm{Mn}$, and $\mathrm{Na}$ mass fraction in pediatric and young adult prostate glands investigated by neutron activation analysis. J Appl Radiat Isot. 2013; 82: 145-51.

[54] Zaichick S, Zaichick V. The effect of age on Ag, Co, Cr, Fe, Hg, Sb, Sc, Se, and Zn contents in intact human prostate investigated by neutron activation analysis. J Appl Radiat Isot. 2011; 69: 827-33.

[55] Zaichick V. Applications of synthetic reference materials in the medical Radiological Research Centre. Fresenius J Anal Chem. 1995; 352: 219-23.

[56] Korelo AM, Zaichick V. Software to optimize the multielement INAA of medical and environmental samples. In: Activation Analysis in Environment Protection. Dubna, Russia: Joint Institute for Nuclear Research. 1993; 32632.

[57] Zhu H, Wang N, Zhang Y, Wu Q, Chen R, Gao J, Chang P, Liu Q, Fan T, Li J, Wang J, Wang J. Element contents in organs and tissues of Chinese adult men. Health Phys. 2010; 98(1): 61-73.

[58] Vlasova ZA. Dynamics of trace element contents in thyroid gland in connection with age and atherosclerosis. Proceedings of the Leningrad Institute of Doctor Advanced Training. 1969; 80: 135-44.

[59] Salimi J, Moosavi K, Vatankhah S, Yaghoobi A. Investigation of heavy trace elements in neoplastic and nonneoplastic human thyroid tissue: A study by proton-induced X-ray emissions. Iran J Radiat Res. 2004; 1(4): 2116.

[60] Boulyga SF, Zhuk IV, Lomonosova EM, Kanash NV, Bazhanova NN. Determination of microelements in thyroids of the inhabitants of Belarus by neutron activation analysis using the k0-method. J Radioanal Nucl Chem. 1997; 222(1-2): 11-4.

[61] Reddy SB, Charles MJ, Kumar MR, Reddy BS, Anjaneyulu Ch, Raju GJN, Sundareswar B, Vijayan V. Trace elemental analysis of adenoma and carcinoma thyroid by PIXE method. Nucl Instrum Methods Phys Res B: Beam Interactions with Materials and Atoms. 2002; 196(3-4): 333-9.

[62] Woodard HQ, White DR. The composition of body tissues. Brit J Radiol. 1986; 708: 1209-18.

[63] Stojsavljević A, Rovčanin B, Krstić D, Borković-Mitić S, Paunović I, Diklić A, Gavrović-Jankulović M, Manojlović D. Risk assessment of toxic and essential trace metals on the thyroid health at the tissue level: The significance of lead and selenium for colloid goiter disease. Expo Health. 2019.

[64] Reitblat MA, Kropachyev AM. Some trace elements in thyroid of the Perm Pricam'ya residents. Proceedings of Perm Medical Institute. 1967; 78: 157-64.

[65] Ataulchanov IA. Age-related changes of manganese, cobalt, coper, zinc, and iron contents in the endocrine glands of females. Probl Endocrinol. 1969; 15(2): 98-102.

[66] Kamenev VF. About trace element contents in thyroid of adults. In: Trace Elements in Agriculture and Medicine. Ulan-Ude, Russia: Buryatia publishing-house. 1963; 12-16.

[67] Neimark II, Timoschnikov VM. Development of carcinoma of the thyroid gland in person residing in the focus of goiter endemic. Probl Endocrinil. 1978; 24(3): 28-32.

[68] Zabala J, Carrion N, Murillo M, Quintana M, Chirinos J, Seijas N, Duarte L, Brätter P. Determination of normal human intrathyroidal iodine in Caracas population. J Trace Elem Med Biol. 2009; 23(1): 9-14.

[69] Forssen A. Inorganic elements in the human body. Ann Med Exp Biol Fenn. 1972; 50(3): 99-162.

[70] Kortev AI, Dontsov GI, Lyascheva AP. Bioelements and a human pathology. Sverdlovsk, Russia: Middle-Ural publishing-house. 1972.

[71] Li AA. Level of some macro- and trace element contents in blood and thyroid of patients with endemic goiter in Kalinin region. PhD thesis. Kalinin, Russia: Kalinin medical institute. 1973.

[72] Boulyga SF, Becker JS, Malenchenko AF, Dietze H-J. Application of ICP-MS for multielement analysis in small sample amounts of pathological thyroid tissue. Microchim Acta. 2000; 134(3-4): 215-22. 
[73] Soman SD Joseph KT, Raut SJ, Mulay CD, Parameshwaran M, Panday VK. Studies of major and trace element content in human tissues. Health Phys. 1970; 19(5): 641-56.

[74] Zakutinsky DI, Parfyenov YuD, Selivanova LN. Data book on the radioactive isotopes toxicology. Moscow: State Publishing House of Medical Literature. 1962.

[75] Kvicala J, Havelka J, Zeman J, Nemec J. Determination of some trace elements in the thyroid gland by INAA. J Radioanal Nucl Chem. 1991; 149(2): 267-74.

[76] Tipton IH, Cook MJ. Trace elements in human tissue. Part II. Adult subjects from the United States. Health Phys. 1963; 9(2): 103-45.

[77] Predtechenskaya VC. Nucleic acids and trace elements in thyroid pathology. Proceedings of the Voronezh Medical Faculty. 1975; 94: 85-7.

[78] Kovalev MM. Trace element contents in normal and goitrous glands. Vrach Delo. 1960; 12: 107-111.

[79] Maeda K, Yokode Y, Sasa Y, Kusuyama H, Uda M. Multielemental analysis of human thyroid glands using particle induced X-ray emission (PIXE). Nucl Instrum Methods Phys Res B. 1987; 22(1-3): 188-90.

[80] Turetskaia ES. Studies on goitrous thyroid glands for iodine and bromine content. Probl Endokrinol Gormonoter. 1961; 7(2): 75-80.

[81] Błazewicz A, Dolliver W, Sivsammye S, Deol A, Randhawa R, Orlicz-Szczesna G, Błazewicz R. Determination of cadmium, cobalt, copper, iron, manganese, and zinc in thyroid glands of patients with diagnosed nodular goitre using ion chromatography. J Chromatogr B Analyt Technol Biomed Life Sci. 2010; 878(1): 34-8.

[82] Pavlyuchenkova EG, Sorokina AN. Spectrographic determination of chromium in thyroid. In: Trace Elements in Agriculture and Medicine. Ulan-Ude, Russia: Buryatia publishing-house. 1963; 23-7.

[83] Kaya G, Avci H, Akdeniz I, Yaman M. Determination of Trace and Minor Metals in Benign and Malign Human Thyroid Tissues. Asian J Chem. 2009; 21(7): 5718-2.6.

[84] Dimitriadou A, Suvanik R, Fraser TR, Pearson JD. Endemic goiter in Thailand. A study contrasting these iodinedeficient goiters with sporadic non-toxic goiters seen in London. J Endocrinol. 1966; 34(1): 23-39.

[85] Braasch JW, Abbert A, Keating FR, Black BM. A note of the iodinated constituents of normal thyroids and of exophthalmic goiters. J Clin Endocrinol Metab. 1955; 15(4): 732-8.

[86] Bolkvadze AI. Contents of electrolytes (K, Na, Ca, I and F) in thyroid and blood under different forms of thyroid pathology. PhD thesis. Tbilisi: Tbilisi medical institute. 1970.

[87] Borodin AE, Sokolova II, Gogolev VG, Makarova MYa. About goitrous thyroid chemical composition. In: Goiter in Amur region. Blagoveshchensk: Khabarovsk publishing-house. 1967; 21-29.

[88] Petrov IC, Alyab'ev GA, Dmitrichenko MM. Contents of iodine, manganese, and cobalt in thyroid and blood in the local residents and migrants of Irkutsk region. In: Trace Elements in Agriculture and Medicine. Ulan-Ude, Russia: Buryatia publishing-house. 1968; 648-51.

[89] Boulyga SF, Petri H, Zhuk IV, Kanash NV, Malenchenko AF. Neutron-activation analysis of trace elements in thyroids. J Radioanal Nucl Chem. 1999; 242(2): 335-40.

[90] Antonova MV, Elinova VG, Voitekhovskaya YaV. Some trace element contents in thyroid and water in endemic goiter region. Zdravookhranenie BSSR. 1966; 9: 42-4.

[91] Stojsavljević A, Rovčanin B, Krstić D, Borković-Mitić S, Paunović I, Kodranov I, Gavrović-Jankulović M, Manojlović D. Evaluation of trace metals in thyroid tissues: Comparative analysis with benign and malignant thyroid diseases. Ecotoxicol Environ Saf. 2019; 183: 109479.

[92] Zagrodzki P, Nicol F, Arthur JR, Słowiaczek M, Walas S, Mrowiec H, Wietecha-Posłuszny R. Selenoenzymes, laboratory parameters, and trace elements in different types of thyroid tumor. Biol Trace Elem Res. 2010; 134(1): 25-40.

[93] Katoh Y, Sato T, Yamamoto Y. Determination of multielement concentrations in normal human organs from the Japanese. Biol Trace Elem Res. 2002; 90(1-3): 57-70.

[94] Schroeder HA, Tipton IH, Nason AP. Trace metals in man: strontium and barium. J Chron Dis. 1972; 25(9): 491517. 
[95] Zaichick V. Sampling, sample storage and preparation of biomaterials for INAA in clinical medicine, occupational and environmental health. In: Harmonization of Health-Related Environmental Measurements Using Nuclear and Isotopic Techniques. Vienna: IAEA. 1997; 123-33.

[96] Zaichick V. Losses of chemical elements in biological samples under the dry aching process. Trace Elements in Medicine. 2004; 5(3): 17-22.

[97] Lansdown AB. Critical observations on the neurotoxicity of silver. Crit Rev Toxicol. 2007; 37(3): $237-50$.

[98] Lansdown AB. Silver in health care: antimicrobial effects and safety in use. Curr Probl Dermatol. 2006; 33: 17-34.

[99] Drake PL, Hazelwood KJ. Exposure-related health effects of silver and silver compounds: a review. Ann Occup Hyg. 2005; 49(7): 575-85.

[100] Pavelka S. Radiometric determination of thyrotoxic effects of some xenobiotics. Rad Applic. 2016; 1(2): 155-8.

[101] Maschkovsky MD. The sedatives. In: The Medicaments. 15th ed. Moscow: Novaya Volna. 2005. 72-86.

[102] Zaichick V. X-ray fluorescence analysis of bromine for the estimation of extracellular water. J Appl Radiat Isot. 1998; 49(12): 1165-9.

[103] Prescott E, Netterstrøm B, Faber J, Hegedüs L, Suadicani P, Christensen JM. Effect of occupational exposure to cobalt blue dyes on the thyroid volume and function of female plate painters. Scand J Work Environ Health. 1992; 18(2):101-4.

[104] Yu R. Cobalt toxicity, an overlooked cause of hypothyroidism. J Endocrinol Thyroid Res. 2017; 1(3): 1-4.

[105] Simonsen LO, Harbak H, Bennekou P. Cobalt metabolism and toxicology--a brief update. Sci Total Environ. 2012; 432: $210-5$.

[106] Li Y, Trush MA. DNA damage resulting from the oxidation of hydroquinone by copper: role for a $\mathrm{Cu}(\mathrm{II}) / \mathrm{Cu}(\mathrm{I})$ redox cycle and reactive oxygen generation. Carcinogenesis. 1993; 14(7): 1303-11.

[107] Becker TW, Krieger G, Witte I. DNA single and double strand breaks induced by aliphatic and aromatic aldehydes in combination with copper (II). Free Radic Res. 1996; 24(5): 325-32.

[108] Glass GA, Stark AA. Promotion of glutathione-gamma-glutamyl transpeptidase-dependent lipid peroxidation by copper and ceruloplasmin: the requirement for iron and the effects of antioxidants and antioxidant enzymes. Environ Mol Mutagen. 1997; 29(1): 73-80.

[109] Kolomiitseva MG. Content and interrelationship of trace elements (iodine, cobalt and copper) in tissues of normal and goiter-bearing thyroid glands. Probl Endokrinol Gormonoter. 1961; 7(6): 63-8.

[110] Fal'fushins'ka HI, Hnatyshyna LL, Osadchuk OĬ, Shydlovs'kyı̆ VO, Stoliar OB. Trace elements storage peculiarities and metallothionein content in human thyroid gland under iodine deficiency euthyroid nodular goiter. Ukr Biokhim Zh. 2014; 86(3): 107-13.

[111] Manz DH, Blanchette NI, Paul BT, Torti FM, Torti SV. Iron and cancer: recent insights. Ann N Y Acad Sci. 2016; 1368(1): 149-61.

[112] Torti SV, Manz DH, Paul BT, Blanchette-Farra N, Torti FM. Iron and Cancer. Annu Rev Nutr. 2018; 38: 97-125.

[113] Selby JV, Friedman GD. Epidemiologic evidence of an association between body iron stores and risk of cancer. Int J Cancer. 1988; 41: 677-82.

[114] Meneghini R. Iron homeostasis, oxidative stress, and DNA damage. Free Radic Biol Med. $1997 ; 23: 783-92$.

[115] Clarkson TW, Magos L. The toxicology of mercury and its chemical compounds. Crit Rev Toxicol. 2006; 36: 60962.

[116] Hazelhoff MH, Bulacio RP, Torres AM. Gender related differences in kidney injury induced by mercury. Int J Mol Sci. 2012; 13: 10523-36.

[117] Clarkson TW, Magos L. The toxicology of mercury and its chemical compounds. Crit Rev Toxicol. 2006; 36: 60962.

[118] Järup L. Hazards of heavy metal contamination. Br Med Bull. 2003; 68:167-82.

[119] Malandrino P, Russo M, Ronchi A, Minoia C, Cataldo D, Regalbuto C, Giordano C, Attard M, Squatrito S, Trimarchi $\mathrm{F}$, Vigneri R. Increased thyroid cancer incidence in a basaltic volcanic area is associated with non-anthropogenic pollution and biocontamination. Endocrine. 2016; 53(2): 471-9. 
[120] Abnoos H, Fereidoni M, Mahdavi-Shahri N, Haddad F, Jalal R. Developmental study of mercury effects on the fruit fly (Drosophila melanogaster). Interdiscip Toxicol. 2013; 6(1): 34-40.

[121] Crespo-López ME, Macêdo GL, Pereira SI, Arrifano GP, Picanço-Diniz DL, do Nascimento JL, Herculano AM. Mercury and human genotoxicity: critical considerations and possible molecular mechanisms. Pharmacol Res. 2009; 60(4): 212-20.

[122] Moncayo R, Moncayo H. Applying a systems approach to thyroid physiology: Looking at the whole with a mitochondrial perspective instead of judging single TSH values or why we should know more about mitochondria to understand metabolism. BBA Clin. 2017; 7: 127-40.

[123] Wolf FI, Cittadini ARM, Maier AM. Magnesium and tumors: Ally or foe? Cancer Treatment Reviews. 2009; 35(4): 378-82.

[124] Zaichick S, Zaichick V, Karandashev V, Nosenko S. Accumulation of rare earth elements in human bone within the lifespan. Metallomics. 2011; 3(2): 186-94.

[125] Horovitz CT. Toxicology, carcinogenicity, and pharmacology of scandium and yttrium. New York, NY, USA: Springer. 2000. 